\title{
Gender, Attitude, and Behavior of Drinking and Smoking in Teenagers
}

\author{
Nikmatur Rohmah ${ }^{1}$, Muhammad Hazmi $^{1 *}$, Siti Kholifah ${ }^{1}$, Taufiq Timur Warisaji ${ }^{1}$ \\ ${ }^{1}$ Universitas Muhammadiyah Jember, Jember, Indonesia \\ "Corresponding author.Email: mhazmi.hazmi@unmuhjember.ac.id
}

\begin{abstract}
The risky behaviours in a teenager were proven to be able to affect health. However, there was not much evidence when it was correlated with the gender. This study aimed to identify the correlation of gender and attitudes towards the behaviours of drinking alcoholic beverages and smoking. The research design used was observational analytic with cross sectional approach. The dependent variables were the behaviours of drinking alcoholic beverages and smoking, and the independent variables were gender and attitudes. The population was 7470 students of Universitas Muhammadiyah Jember. The sampling was done by using simple random sampling and 365 samples were obtained. Data collection used was questionnaires and data analysis used was path analysis. The results show that there was a significant correlation between attitude and behaviour of smoking, between the behaviours of drinking alcoholic beverages and smoking, between gender and the behaviour of smoking, between the behaviours of drinking alcoholic beverages and smoking, between the gender and behaviour of smoking, and between attitude and behaviour in drinking alcoholic beverages. Therefore, the good attitudes to drinking alcoholic beverages and smoking has a potential to reduce smoking behaviour, especially in teenagers.
\end{abstract}

Keywords: gender, attitude, drinking, smoking, teenagers

\section{INTRODUCTION}

Teenager is a stage of a transition period from childhood to adulthood. Teenager is a stage of a development between puberty, biological transition period in childhood and adulthood [1]. The number of teenagers in Indonesia are 43.5 million or around $18 \%$ of the population. In the world, it is estimated that the number of teenager group is 1.2 billion or $18 \%$ of the world's population. The number of teenagers aged 15-19 years old in Indonesia in 2016 was balanced, namely 10,614,306 men and 10,266,428 women [2]. Likewise, male and female teenagers in East Java and in Jember were balanced [3]. The growth and development of teenagers take place rapidly both physical, psychological and intellectual aspects. Teenagers have a great curiosity, like to have adventure and challenges and have a tendency to do without careful consideration. Teenagers often try to carry out risky behaviours which had a negative impact in the short and long term. Risk behaviours in teenagers are proven to cause deviant behaviour which can increase the potential health disorders in the teenagers.

The risk behaviours of teenagers which related to health are smoking and drinking alcoholic beverages. However, there is not much evidence of some things which becomes the formation causes of teenagers' risk behaviour comes from the teenagers, namely gender and attitude. Attitude means readiness or willingness to act, attitude is closed and a predisposition of a person's behaviour towards a stimulus [4]. Gender is related to differences in attitude and behaviour based on gender. This study is intended to prove the correlation between sex and attitudes toward the behaviour of drinking alcoholic beverages and smoking in teenagers.

\section{METHOD}

The research design used was observational analytics with the cross-sectional approach. The research was conducted at University of Muhammadiyah Jember East Java Province Indonesia. The dependent variables were gender and attitude. The population was the students of University of Muhammadiyah Jember East Java Indonesia totalling 7470 people. The sampling was done by using simple random sampling and it was obtained 365 samples. The flow of sampling can be seen in the picture below. Data collection used was questionnaires distributed electronically. The univariate analysis was used to see the frequency distribution. The bivariate analysis was used to see the relationship between variable data characteristics of the sample. Multivariate analysis used path analysis. 
The questionnaire was distributed to active students in the even semester of 2018/2019 $(n=7470)$

The questionnaire was sent back

$$
(\mathrm{n}=510)
$$

Questionnaire got responses ( $\mathrm{n}$

$$
=503 \text { ) }
$$

Questionnaire got single responses

$$
(\mathrm{n}=480)
$$

The questionnaire was filled completely $(n=400)$

Respondents included in the study $(\mathrm{n}=365)$

Figure 1 Flow of respondent retrieval

\section{RESULTS AND DISCUSSION}

\subsection{Respondents' Characteristics}

The total of 365 respondents were between 17 to 27 years old resulting in the mean 20.56 years and SD 1.422, who came from ten different study programs. In descending order, the study programs were as follows Nursing (S1) 40.3\% (147), Law 19.7\% (72), Nursing (D3) $15.3 \%$ (56), Biology education $8.2 \%$ (30), Informatics Engineering $7.7 \%$ (28), Bahasa Indonesia education $3.6 \%$ (13),
Electrical Engineering 2.2\% (8), Accounting 1.6\% (6), Mechanical Engineering $1.1 \%$ (4), and System of Informatics $0.3 \%$ (1). To be categorized further based on the nature of the study program, whether exact or non-exact study program, it is obtained that 244 respondents $(66.9 \%)$ were from the exact study program and $121(33.1 \%)$ from the non-exact study program. This finding indicates that the participation level seen from the returned questionnaires of the exact students was twice that of the non-exact.

As categorized from the gender, 62.7\% (299) of the respondents were female and the rest $37.3 \%$ (136) were male. Their participation differs as the proportion of female students returning the questionnaire was higher than the male students by $1.7 \%$.

Table 1 The correlation between gender and attitude with drinking alcohol and smoking behaviour in teenagers

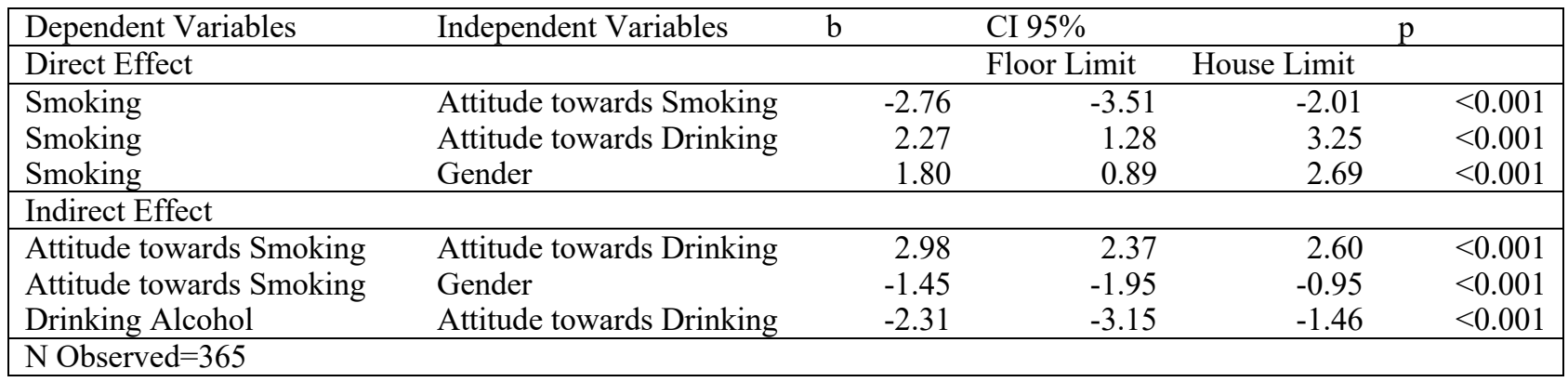




\subsection{Path Analysis}

The direct effects include the following: 1) attitude towards smoking behaviour $=-2.76 ; 2$ ) drinking alcohol behaviour to smoking $=2.27$; and 3 ) gender to smoking behaviour $=$ 1.80 , resulting in the total of direct effect $=1.31$. Meanwhile, the indirect effect is calculated as follows: 1) Gender to attitude to smoking behaviour $-1.45 \times-2.76=$ $4.002 ; 2)$ Attitude to drinking alcohol to attitude towards smoking to smoking behaviour $2.98 \times-2.76=-8.2248$; and 3) attitude towards drinking to smoking behaviour $-2.31 \mathrm{x}$ $2.27=-5.2437$. The total of indirect effect is -9.4665 . So, the total of all effects is $=-8.1565$.

\subsection{The Correlation Between Attitude and Behaviour of Smoking}

The study found that every increase of 1 unit in attitude will decrease 2.76 units of smoking behaviour. Attitude is internal, not yet an observable behaviour. Generally, a good attitude is based on adequate knowledge of something. Teenagers in this study have shown excellent knowledge about smoking $(99.5 \%)$. They could name threats or diseases resulted from smoking, such as heart failure and coronary diseases, lung cancer, cancer in respiration or nonrespiration organ, pneumonia, stroke, pregnancy and embryonic problems, infertility, addiction, impotence, prostate problems, and harming the passive smokers. The finding indicates that the knowledge is adequate, therefore supporting the study that $92.8 \%$ of teenager's attitude is good.

An excellent attitude may result in more permanent good behaviour. In relation to smoking, the attitude is supposed to prevent smoking behaviour. However, the study found that $9.6 \%$ (33) of respondents disagreed or highly disagreed but still smoke sometimes even frequently. Such thing is acceptable, somehow, because the closeness of relationship among variables is -0.55 , meaning that attitude determines only $55 \%$ to smoking, while the rest $45 \%$ may be influenced by factors. Salawati \& Amalia [5] confirming the study, found that teenagers at university (from health and nonhealth faculties) are well informed about the dangers of smoking, but most of them still perform smoking. They argue that smoking feels good, is an entertaining activity, and releases stresses [5]. Moreover, Xu et al. [6] also found that the correlation between the attitude towards smoking and smoking itself is not correlated with the knowledge about and behaviour of smoking In addition, Niu L. et al. [7] confirm that $68.9 \%$ of their respondents would be very glad if invited to smoke, and denies the relationship between attitude and attempts to stop smoking.

\subsection{The Correlation Between Drinking Alcohol and Smoking Behaviour}

Many have found that drinking alcohol is correlated with smoking. Similarly, this study found a significant relationship, that every increase of 1 unit in drinking behaviour means decrease of 2.27 units of smoking.
Teenagers who confirm drinking alcohol is 7.7 with the closeness value of 0.42 . It means that drinking alcohol contributes $42 \%$ to smoking behaviour, leaving the $58 \%$ contributed by other factors. Interestingly, 9 people confirmed drinking $(32.1 \%$ or $9 / 28)$ state that they never smoke. This could indicate that a drinker cannot be justified as a smoker. However, $67.9 \%$ of smoking drinker is undeniable.

Teens are indicated with acquiring self-freedom, having high curiosity, obtaining acceptance in peers, building selfesteem and self-identity. Building self-identity may take a start when a teen interacts with his/her peers. The idea of to be accepted in the group will allow him/her to behave as the group does. It applies as well to drinking and smoking teenagers who are more prone to problems when they grow older. Strong et al. [8] argue that a smoking teenager has five times more chances of smoking when they become adult, compared to those who irregularly smoke in their teenage period. A regular smoker shows 1.99 of higher possibility to have problems in alcohol abuse, 1,68 of consuming marijuana, 1.60 of using cocaine, and 3.44 of being addicted to drug and drug abuse when they grow up [8].

Teenagers at university who are smoking and drinking at the same time are assumed to be parents in the next five years. If they fail to control their drinking and smoking behaviour, they will likely to affect their kids, as it is confirmed by Knopik. et. al. [9] that an alcoholic and smoking parent will increase the risk of their children behaviour.

\subsection{The Correlation Between Gender And Smoking Behaviour}

The bivariate analysis results that the male students have greater tendency to smoke 11.95 times than the female (CI $95 \% 5.79$ to 24.66). Meanwhile, the female has a greater chance of to not smoke 4 times than the male. The male students have 0.35 smaller chance of to not smoke than the female. They demonstrate the possibility to drink alcohol 3.97 times greater than the female counterparts (CI 95\% 1.74 to 9.05 ). The female students have a greater possibility to not drink alcohol twice than that of the male, while the male only has the possibility by 0.51 smaller than the female students. Such findings are in line with those found by Pengyu et. al. [10].

Fucito et al. [11] confirmed that the difference between male and female smokers is $\mathrm{p}=0.004$ with the prevalence of male $73 \%$ and female $27 \%$. Another study in China reports that in 2012 smokers in China consists of 52.9\% male and $2.4 \%$ female smokers. His study involved 536 young smokers within the age of $18-45$ years old. He also found that there is correlation between the attitude towards smoking and educational level, in which the higher education contributed the most by $47 \%$ [6]. Lee. et.al. [12] investigating 210 teenagers of $\geq 18$ years old found that the number of male smokers is a little greater than that of the female. The implicit attitude is related with the attempt to stop smoking has only 0.71 of chance. Niu et al. [7] studying 682 medical teachers found that $48.7 \%$ were smoking (77.5\% of male and $18.1 \%$ of female). The respondents 
confessed their first-time smoking when they started going to university and $59 \%$ still reported smoking both at the campus and at the hospital.

The data demonstrate that teenage, adult and grown-up smokers are dominated by male. Moreover, it has been described that the information about the dangers of smoking has been well known by nearly all respondents. Niu, who investigated the population of medical teachers also found that the smokers are well informed about the dangers but unable to quit smoking. Such behaviour may negatively affect the teenage smokers who are exposed to their smoking lecturers. The characteristics of male who want to dominate their groups making this gender proud when smoking. Moreover, some teenage males feel less of a man when not smoking. In relation to culture, the Javanese culture gives a bolder constraint for females in smoking. A smoking woman is taken as a taboo and negatively regarded.

\subsection{The Correlation Between Attitude Towards Drinking and Smoking (2.98)}

The attitude towards drinking is significantly correlated with that towards smoking. Every unit increase in the attitude towards drinking will increase 2.98 units of smoking. Some dangers of drinking to a human body includes for a moderate dosage, drinkers may experience troubles in sleeping, fast but not sound asleep, troubles in peripheral neuropathy due to the decline in the centre of nerve function in arms and legs, and worsen by the lack of Vitamin B1 intake; its symptoms may include degeneration affecting the walking manner and balance [13]. The present study shows that $98.1 \%$ of respondents demonstrate excellent knowledge about the dangers in drinking alcohol. They mention kidney problems, brain damage, coronary, digestion, liver, and nerve diseases, intoxicating, causing unconsciousness, addiction, infertility, mental problems, and death. The closeness of relationship of the two variables is 0.61 , meaning that attitude towards drinking contributes $61 \%$ to the attitude of smoking, while the rest is affected by other factors. The relationship is positive, indicating that if one disagrees with the drinking behaviour, he/she will likely to disagree with smoking as well.

Attempts to reduce smoking can start by improving a preventative attitude towards smoking and drinking. As this study supports, that there is an indirect effect from the attitude towards drinking to that towards smoking and to smoking behaviour by -8.224 . This finding means that every increasing unit of attitude towards drinking and smoking altogether will reduce the smoking behaviour by 8.224. The data becomes the basis for arranging a strategic plan in educating smokers by integrating the two problems - smoking and drinking. It is expected that it could raise smokers' motivation to quit smoking.

Salgado et al. [14], investigating 1659 students of 20-30 years old at University of Buenos Aires Medical School obtained $453(27.3 \%)$ active smokers. The smokers seem to disagree with the prohibition to smoke indoor, especially around the campus area. Attempts to help them quit smoking have been done, but non-has given a satisfying result. It is not unusual to see students from health/medical faculty's smoke. The fact that smoking can increase LDL [15] and stroke possibilities; still cannot make them quit smoking. Another attempt proposed by Abdullah et al. [16] is a virtual coach with embodied conversational agent (ECA). However, it is not known whether the attempt has a constant effective result.

\subsection{The Correlation Between Gender And Attitude Towards Smoking (-1.45)}

The present study indicates that $98 \%$ of female students demonstrate disagreement and high disagreement towards smoking. This magnitude is supported by the attitude. The male students approving smoking behaviour has 4.002 points of smoking chances higher than the chances for female. A previous study found that men show more approval to the following statements, than the women: patients are having problems thus an obligation to quit smoking means an added problem, patients cannot quit smoking, it is better for doctors to use their time to do other things other than telling patients to quit smoking, there is no gender differences in smoking prohibition [14]. A study in Norway informs that the prevalence of drinkers increases every decade, both in the men and women [17].

The approving attitude of women to smoking is $14.16 \%$ lower than that of the men. Meanwhile, the men show $14.2 \%$ lower of approval than the women. The attitude has opened more chances for men to smoke. As Sheals et al. conducting a meta-analysis, suggest that Pooled found $42.2 \%$ of respondents report resistance to quit smoking. $40.5 \%$ demonstrate a negative attitude towards quitting smoking while $45.0 \%$ have a permissive attitude towards it. Generally, $51.4 \%$ of respondents are not interested in quitting These two attitudes, negative attitude towards quitting smoking and approval for smoking can cause someone to hardly avoid smoking. As the men physical biologically have a stronger character, most would feel that they would look stronger or more masculine when smoking. Such approving attitude to smoking is confirmed in teenagers at universities. This may be due to the building of self-identity. It occurs as a result of interaction with peers. An attitude approved by the peers is more tempting to follow than his own attitude or stance. A group of male students will likely to create a masculine identity by smoking.

\subsection{The correlation between attitude and behaviour of drinking}

The study obtained that the attitude has a negative effect to drinking and to smoking behaviour as much as -5.24 , meaning that 1 disagreeing unit of attitude coupled with non-drinking behaviour will reduce the smoking behaviour by 5.24 units. This information is significant, regarding the close relationship between drinking and smoking. In order to reduce smoking, the improvement of attitude towards drinking and drinking behaviour can be done. However, this behaviour should be taken into consideration because drinkers are prone to alcohol abuse or addiction, such as: 1) 
[3] BPS, "Jumlah Penduduk Indonesia Menurut Provinsi Jawa Timur 2016,” Badan Pusat Statistik, 2016. .

[4] Notoadmojo, Promosi Kesehatan dan. Perilaku Kesehatan. Jakarta: Rineka Cipta, 2012.

[5] T. Salawati dan R. Amalia, "Perilaku Merokok Di Kalangan Mahasiswauniversitas Muhammadiyah Semarang," in PROSIDING SEMINAR NASIONAL, 2010.

There is a significant relationship between attitudes and smoking. More, a significant relationship is found between drinking and smoking, as it is significant between gender and smoking. Moreover, there is a significance in attitude towards drinking and that towards smoking. Gender is found significant with attitude towards smoking. Finally, there is a significant relationship between attitude and behaviour of drinking alcohol.

The attitude of male students towards smoking and drinking alcohol within universities needs to be improved. Health and spiritual based program can be held to achieve it. Students need to demonstrate an approving attitude to willingness to quit smoking. The good attitude towards drinking and smoking is positively potential to reduce smoking behaviour. It all should aim to maintain health and optimize growth and development of teenagers.

\section{FUNDING SOURCES}

The present study was fully funded by the LPPM of Universitas Muhammadiyah Jember, East Java, Indonesia.

\section{COMPLIANCE WITH ETHICAL STANDARD}

The study is an observational analysis that complies with autonomy and confidentiality of respondents and minimal damage or loss. Statement of agreement to proceed has been declared in prior to items of questionnaires. Approvals were given by the Vice Rector 1, the Dean, and Head of the department.

\section{REFERENCES}

[1] Kementerian Kesehatan RI, "Peraturan Menteri Kesehatan RI Nomor 25 tahun 2014 Tentang Upaya Kesehatan Anak,” Jakarta: Jakarta, 2014.

[2] BPS, "Jumlah Penduduk Indonesia," Badan Pusat Statistik, 2016. .
[6] X. Xu, L. Liu, M. Sharma, dan Y. Zhao, "SmokingRelated Knowledge, Attitudes, Behaviors, Smoking Cessation Idea and Education Level among Young Adult Male Smokers in Chongqing, China," Int. J. Environ. Res. Public Health, vol. 12, hal. 2135-2149, 2015.

[7] L. Niu, D. Luo, V. M. B. Silenzio, S. Xiao, dan Y. Tian, "Are Informing Knowledge and Supportive Attitude Enough for Tobacco Control? A Latent Class Analysis of Cigarette Smoking Patterns among Medical Teachers in China," Int. J. Environ. Res. Public Health, vol. 12, hal. 12030-12042, 2015.

[8] C. Strong, H.-S. Juon, dan M. E. Ensminger, "Effect of Adolescent Cigarette Smoking on Adulthood Substance Use and Abuse: The Mediating Role of Educational Attainment," HHS Public Access, vol. 51, no. 2, hal. 141-154, 2018.

[9] V. S. Knopik, A. C. Heath, K. K. Bucholz, A. F. Pamela, dan M. Waldron, "Genetic and environmental influences on externalizing behavior and alcohol problems in adolescence: A female twin study," Pharmacol Biochem Behav, vol. 93, no. 3, hal. 313321, 2010.

[10] W. Pengyu, "The Causal Relationship between Socioeconomic Status and Smoking Behavior : Evidence from Canada," Adv. Econ. Bus. Manag. Res., vol. 51, no. Icemgd, hal. 44-56, 2018.

[11] L. M. Fucito, A. Park, S. B. Gulliver, M. E. Mattson, R. V. Gueorguieva, dan S. S. O'Malley, "Cigarette Smoking Predicts Differential Benefit from Naltrexone for Alcohol Dependence," Biol Psychiatry, vol. 72, no. 10, hal. 832-838, 2013.

[12] H. S. Lee, M. Addicott, L. E. Martin, K. J. Harris, K. Goggin, P. Kimber, C. A. Patten, F. J. Mcclernon, dan K. Fleming, "Original investigation Implicit Attitudes and Smoking Behavior in a Smoking Cessation Induction Trial," Nicotine Tob. Res., vol. 20, no. 1, hal. 58-66, 2018. 
[17] G. H. Bratberg, S. C. Wilsnack, R. Wilsnack, S. H. Haugland, S. Krokstad, E. R. Sund, dan J. H. Bjørngaard, "Gender differences and gender convergence in alcohol use over the past three decades ( 1984 - 2008 ), The HUNT Study, Norway," BMC Public Health, hal. 1-12, 2016.

[18] L. P. Spear, "Adolescent alcohol exposure : are there separable," Physiol Behav, vol. 148, no. 1, hal. 122-130, 2016.

[19] Y. Tebay, “Gambaran Perilaku Konsumsi Minuman Beralkohol Pada Mahasiswa Asal Kabupaten Dogiyai Provinsi Papuadi Kota Tomohon Tahun 2015.," e.libary fkm unsrat, 2015.

[20] R. V. D. Issakh Raynald A., Ottay Ronald, "Gambaran perilaku remaja terhadap kebiasaan kecamatan tenga kabupaten minahasa selatan," J. eBiomedik, vol. 4, hal. 5-10, 2016. 